\title{
DEVELOPMENT AND VALIDATION OF A RP-HPLC METHOD FOR THE ANALYSIS OF RIMANTADINE HYDROCHLORIDE IN MEDICINAL FORM
}

\author{
J. Mamatha ${ }^{1, *}$ and N. Devanna ${ }^{2}$ \\ ${ }^{1}$ Department of Chemistry, G. Pullaiah College of Engineering and Technology, \\ A.P. State \\ ${ }^{2}$ Department of Chemistry, JNTU College of Engineering, Anantapuramu, A.P. State \\ *E-mail:mamatha@gpcet.ac.in
}

\begin{abstract}
The aim of the research work was to conduct precolumn derivatization of Rimantadine hydrochloride (RMT) with Anthraquinone - 2 - sulphonyl chloride (AQSC) to develop a validated, selective, precise and accurate RP-HPLC UV method for the analysis of RMT - AQSC derivative in its Medicinal form.

The isocratic mobile phase for the $\mathrm{C}-18$ column consisted of Ethylnitrile and $0.005 \mathrm{M} 1$ - octane sulfonic acid sodium salt monohydrate buffer (pH adjusted to 6.7) in 60:40 volume ratio. Flow rate maintained at one millilitre in one minute at ambient temperature. The ideal UV detection wavelength for RMT derivative was $259 \mathrm{~nm}$.

The retention time for both API and the medicine was 6.79 minutes. Linearity was satisfied over a range of $50 \mathrm{ppm}$ to $250 \mathrm{ppm}$ with a correlation coefficient (r) value 0.999 . Percentage RSD for precision, accuracy and robustness were less than 2. The LOD and LOQ were $1.32 \mathrm{ppm}$ and $4.0 \mathrm{ppm}$ respectively. Validation was done as per $1 \mathrm{CH}$ guidelines and all the results were with in the limits.
\end{abstract}

Keywords: RP-HPLC, Method validation, Derivatization (DRT), ICH.

(C) RASĀYAN. All rights reserved

\section{INTRODUCTION}

RMT (Fig.-1) $\mathrm{C}_{12} \mathrm{H}_{22} \mathrm{ClN}$, molecular weight, $215.76 \mathrm{~g} / \mathrm{mol}$ is 1-(1-Adamantyl) Ethanamine Hydrochloride .It is an antiviral drug against influenza virus $\mathrm{A}$ and prophylaxis in children and is taken orally. By resisting the breakage of the protective shells of the virus, RMT stops viral multiplication in the host cell. RMT alone shows no absorption in the UV - visible region, hence it is derivatized ${ }^{1}$ to enable HPLC detection. The earlier works for the determination of RMT included analysis of RMT by GC $-\mathrm{MS}^{2}$, and using capillary zone electrophoresis ${ }^{3}$.

New separation method for tricyclic antiviral drugs was developed ${ }^{4}$. Previous works included determination of RMT using IR Analysis ${ }^{5}$, online post column $\mathrm{DRT}^{6}$, fluorescent probe ${ }^{7}$, UV-visible spectrophotometry $^{8}$, UHPLC coupled with orbitrap mass spectrometry ${ }^{9}$, use of AQSC for RMT analysis ${ }^{10}$, and simultaneous analysis using tandem mass spectrometry ${ }^{11}$. The present work focused on RP-HPLC method development ${ }^{12}$ and its validation ${ }^{13}$.

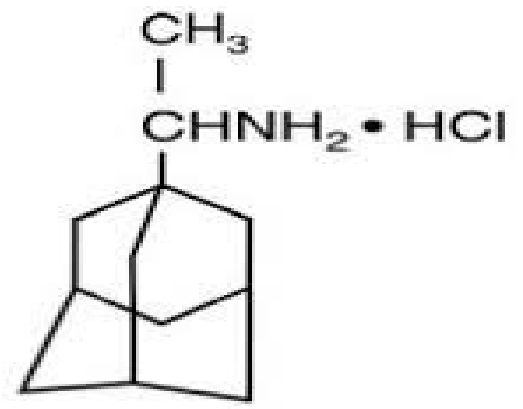

Fig.-1:Rimantadine hydrochloride (RMT) 
RASĀYAN J. Chem.

Vol. 11 | No. 1 | 300 - 306 | January - March | 2018

\section{Chemicals}

\section{EXPERIMENTAL}

A sample of RMT (API) was received from a Biopharm Limited in West India. Flumadine ${ }^{\circledR}$ tablets were bought from the pharmacy. AQSC was prepared in the laboratory. Octane sulfonic acid (OSA), sodium hydroxide (SH), dichloromethane (DCM), Hydrochloric acid $(\mathrm{HCl})$, Anhydrous sodium sulfate (SS) orthophosphoric acid, Ethylnitrile (EN) all suitable for HPLC analysis were purchased from Sigma Aldrich limited.

Table-1: Instrumentation

\begin{tabular}{l|l}
\hline Column & C $-18(250 \mathrm{~mm} \times 4.6 \mathrm{~mm})$ \\
\hline Decteror & UV - VIS, Japan \\
\hline Pump & LC -10 ATVP, Japan \\
\hline Injection valve & $7725 \mathrm{i}$ model, 20 units \\
\hline Syringe & 50 units. \\
\hline Software & Baseline N2000 \\
\hline
\end{tabular}

Table-2: Chromatographic Conditions

\begin{tabular}{l|l}
\hline Mobile Phase & EN : $0.005 \mathrm{M}$ OSA $60: 40(\mathrm{~V} / \mathrm{V})$ \\
\hline Flow rate (FR) & $1 \mathrm{ml}$ per minute \\
\hline Injection volume & 20 units \\
\hline Wavelength & $260 \mathrm{~nm}$ \\
\hline Elution type & Isocratic \\
\hline Buffer pH & 6.7 \\
\hline Temperature & Ambient \\
\hline
\end{tabular}

\section{Preparation of Reagents \\ DRT of RMT (API and sample)}

RMT 50mg was dissolved in water, mixed with SH in a 100ml flask and stirred. DCM $15 \mathrm{ml}$ and AQSC (1.0 millimolar in $25 \mathrm{ml}$ DCM) were added to the above flask within 30 minutes and stirred for one hour. The aqueous phase was removed, the organic phase was washed three times with $1 \mathrm{M} \mathrm{HCl}$ and dried over SS. DCM was removed by rotatory evaporation to give a residue which was RMT - AQSC derivative and it was subjected to RP - HPLC analysis(DRT Reaction, Fig.-2).

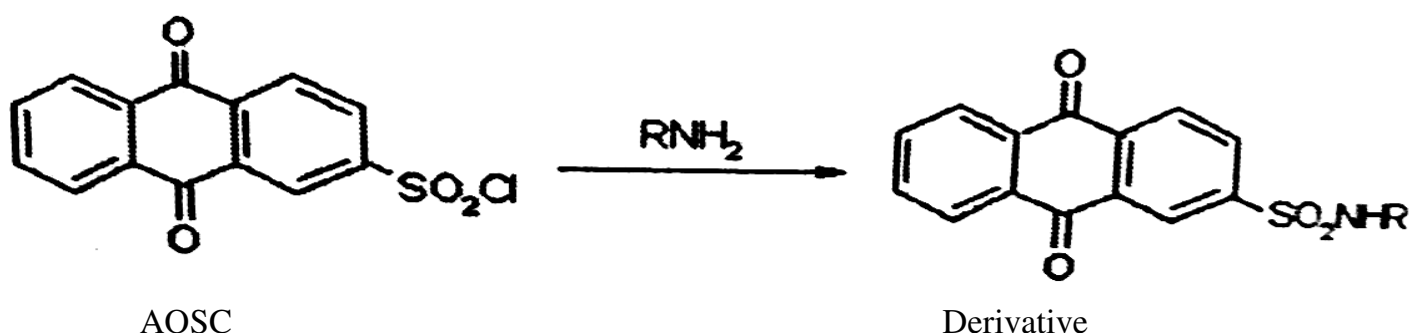

Fig.-2

\section{Preparation of stock and working standard (WS) solutions}

The diluent used for all solutions was EN. RMT - AQSC derivative prepared from RMT (AP1) 50mg was diluted with EN up to the mark in a $50 \mathrm{ml}$ volumetric flask. The concentration of this solution was 1000 microgram per milliliter or $1000 \mathrm{ppm}$ (part per million). From the stock solution, WS solution of $150 \mathrm{ppm}$ was prepared by suitable dilution in a $10 \mathrm{ml}$ flask. All the prepared solution were micro-filtered and sonicated for sufficient time.

\section{Preparation of Sample Solution}

Ten Flumadine ${ }^{\circledR}$ tablets containing RMT active ingredient were weighed and their average weight was noted. All the tablets were powdered and a part of the powder equal to 50mg of RMT as given in the label information of the tablets was separated and subjected to DRT with AQSC to form the derivative, which 


\section{RASĀYAN J. Chem.}

Vol. 11 | No. 1 |300 - 306 | January - March | 2018

was transferred into a 50ml flask and diluted with EN up to the mark to result in a $1000 \mathrm{ppm}$ solution. $150 \mathrm{ppm}$ sample solution was prepared from the above solution by suitable dilution.

\section{Mobile Phase preparation}

$0.005 \mathrm{M}$ OSA $\left(\mathrm{C}_{8} \mathrm{H}_{17} \mathrm{NaO}_{3} \mathrm{~S} . \mathrm{H}_{2} \mathrm{O}, 234.3 \mathrm{gm} / \mathrm{mol}\right)$ buffer solution was prepared in HPLC grade water with $\mathrm{pH}$ adjusted to 6.7. Mobile phase composed of 60:40 v/v ratio of EN and OSA buffer.

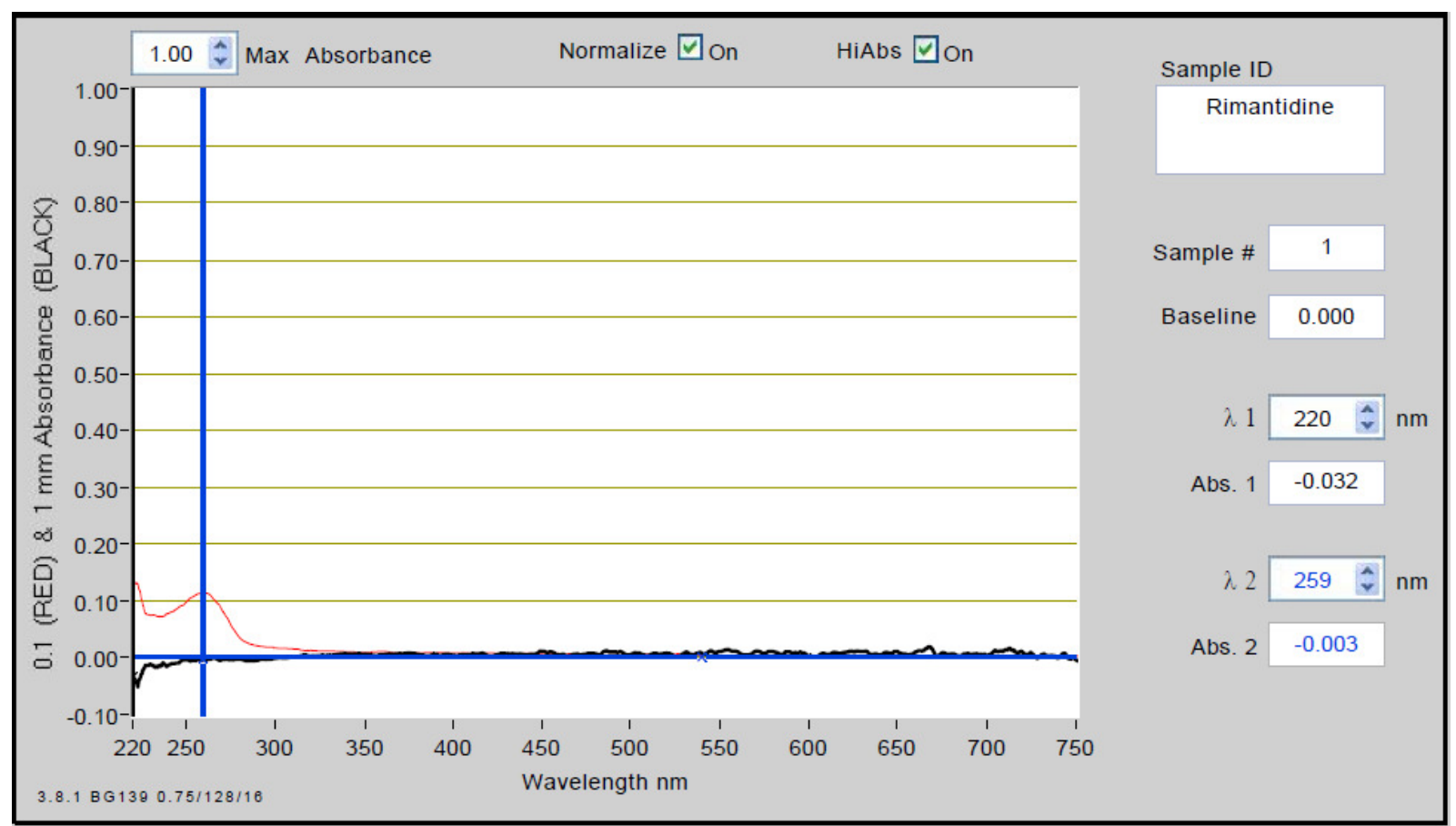

\section{System Suitability (ST)}

Fig.-3: UV-Spectrum of RMT - Derivative

To know the resolution and reproducibility of the method ST Study was done.

RMT (WS) was injected into the HPLC system to facilitate the study of 6 different chromatograms. The acceptance criteria for resolution (Rs), Tailing factor (T), Asymmetry (K), Theoretical plates $(\mathrm{N})$, standard deviation (SD) and \% RSD percent relative standard deviation for Retention time (RT), Peak area (PA) and Peak height (PH) were checked (Table-3).

Table-3: System Suitability

\begin{tabular}{c|c|c}
\hline ST Parameter & Reference Value & Results \\
\hline RT & $\%$ RSD $\leq 1$ & 0.0601 \\
\hline PA $(\mathrm{n}=6)$ & $\%$ RSD $\leq 1$ & 0.9745 \\
\hline PH & $\%$ RSD $\leq 1$ & 0.51721 \\
\hline Rs & Rs $\geq 2.0$ & 12.956 \\
\hline T & $\mathrm{T} \leq 2.0$ & 1.048 \\
\hline K & $\mathrm{K} \leq 2.0$ & 1.075 \\
\hline $\mathrm{N}$ & $\mathrm{N} \geq 2000$ & 7720.263 \\
\hline
\end{tabular}

\section{Estimation of RMT in sample}

The Response factor (RF) of the WS and the sample were calculated separately from the average of six peaks to calculate the amount of the drug.

Amount of the drug $=\frac{\text { R.Fof the sample }}{\text { R.Fof the WS }} \times$ strength of the W.S 
RASĀYAN J. Chem.

Vol. 11 | No. 1 | 300 - 306 | January - March | 2018

\section{Method Validation}

Validation was done as per 1CH Q2(R1) guidelines for linearity, Accuracy, Precision, Robustness, Limit of detection (LOD) and limit of Quantification (LOQ).

\section{RESULTS AND DISCUSSION}

All the ST measurements met the criteria (as per given in Table-3). RT of the Blank (Mobile phase) was 3.34 minutes (Fig.-4). RT of the RMT (WS) was 6.79 minutes (Fig.-5). RT of the RMT (sample) was also 6.79 minutes (Fig.-6).

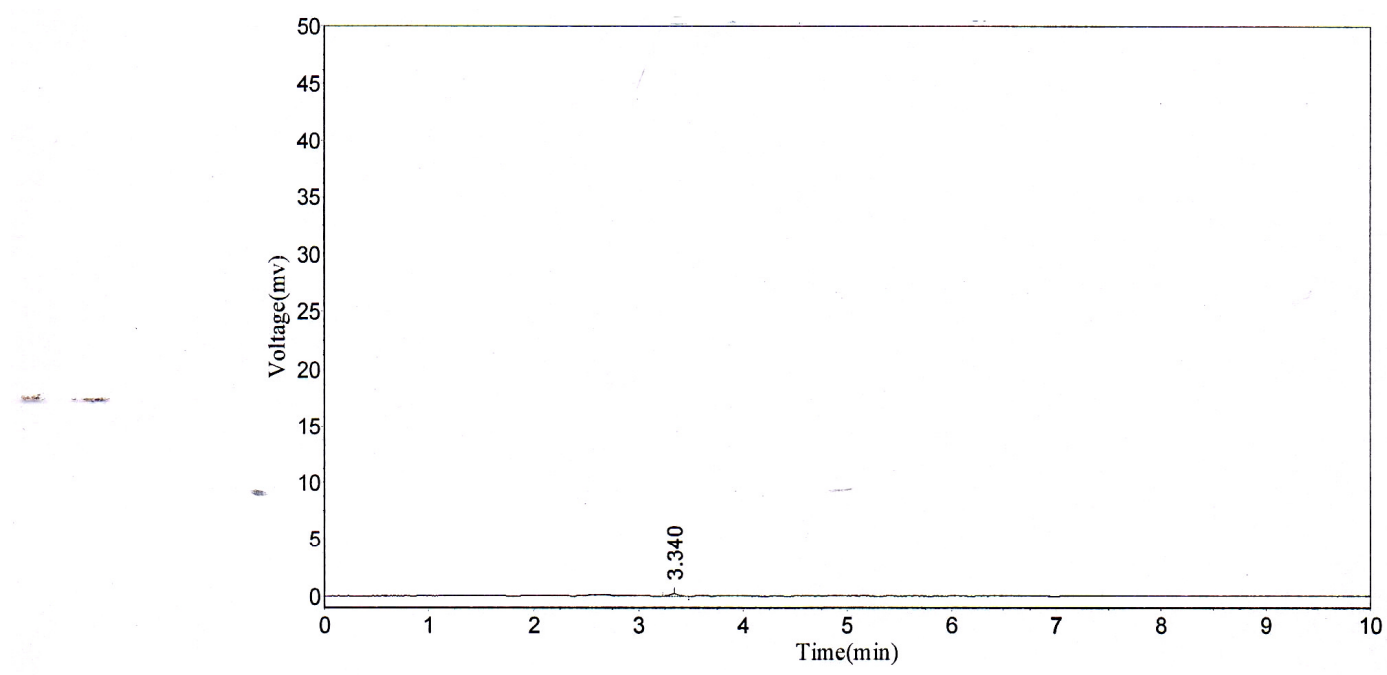

\begin{tabular}{|c|c|c|c|c|c|c|c|}
\hline \multicolumn{8}{|c|}{ Results } \\
\hline Peak No. & \multicolumn{2}{|c|}{ Peak ID } & Ret Time & \multicolumn{2}{|l|}{ Height } & \multirow{2}{*}{$\frac{\text { Area }}{1091.000}$} & \multirow{2}{*}{$\begin{array}{c}\text { Conc. } \\
100.0000\end{array}$} \\
\hline 1 & & & 3.340 & 211.600 & & & \\
\hline Total & & & & 211.600 & & 1091.000 & 100.0000 \\
\hline \multicolumn{8}{|c|}{ System Evaluation } \\
\hline Peak No. & Peak ID & Ret. Time & Half-Peak Width & Theoretical levels & Resolution & Tail Factor & Asymmetry \\
\hline 1 & & 3.340 & 0.078 & 10071.855 & 0.000 & 1.143 & 1.341 \\
\hline
\end{tabular}

\section{Linearity}

Fig.-4: Blank Chromatogram

Five solution levels ranging from $50 \mathrm{ppm}$ to $250 \mathrm{ppm}$ were prepared from the WS. Each level in the range was injected thrice. The calibration curve of PA versus strength in ppm was plotted. The linear regression equation and the correlation coefficient ( $r$ ) value depicted the linear relationship between PA and the concentration of the solution. (Table-4 and Fig.-7).

\section{Accuracy}

$80 \%, 100 \%$ and $120 \%$ of WS solutions were spiked to sample solution and each injected thrice. The average PA study depicted a percent recovery of 101.68, 101.87 and 98.45 from each level of addition and was within the acceptance limits (Table-5).

\begin{tabular}{c|c|c}
\multicolumn{3}{|c}{ Table-4: Linearity } \\
\hline Strength $(\mathrm{ppm})$ & PA( $\mathrm{n}=3)$ & \% RSD \\
\hline 50 & 24762.93 & 0.4401 \\
\hline 100 & 50324.16 & 0.504695 \\
\hline 150 & 72088.5 & 0.4077 \\
\hline 200 & 97907.76 & 0.861 \\
\hline 250 & 121061.60 & 0.750228 \\
\hline
\end{tabular}


RASĀYAN J. Chem.

Vol. 11 | No. 1 |300 - 306 | January - March | 2018

\begin{tabular}{c|c}
\hline $\begin{array}{c}\text { Regression line Equation } \\
\mathrm{Y}=483.7 \mathrm{x}+559.3\end{array}$ & $\mathrm{R}^{2}=0.999$ \\
\hline Slope $(\mathrm{m}) 483.7$ & Intercept $(\mathrm{c})=559.3$ \\
\hline
\end{tabular}

Table-5: Accuracy

\begin{tabular}{|c|c|c|c|c|c|c|}
\hline \multirow{2}{*}{ Sample } & \multirow{2}{*}{$\%$ of WS } & \multicolumn{2}{|c|}{ Amount WS (ppm) } & \multirow{2}{*}{$\mathrm{PA}(\mathrm{n}=3)$} & \multirow{2}{*}{$\%$ RSD } & \multirow{2}{*}{$\begin{array}{c}\text { Recovery } \\
(\%)\end{array}$} \\
\hline & & Spike & Found & & & \\
\hline 1 & 80 & 120 & 122.019 & 58916.9 & 1.00 & 101.68 \\
\hline 2 & 100 & 150 & 152.818 & 73788.6 & 0.292 & 101.87 \\
\hline 3 & 120 & 180 & 177.225 & 85573.5 & 0.639 & 98.45 \\
\hline
\end{tabular}

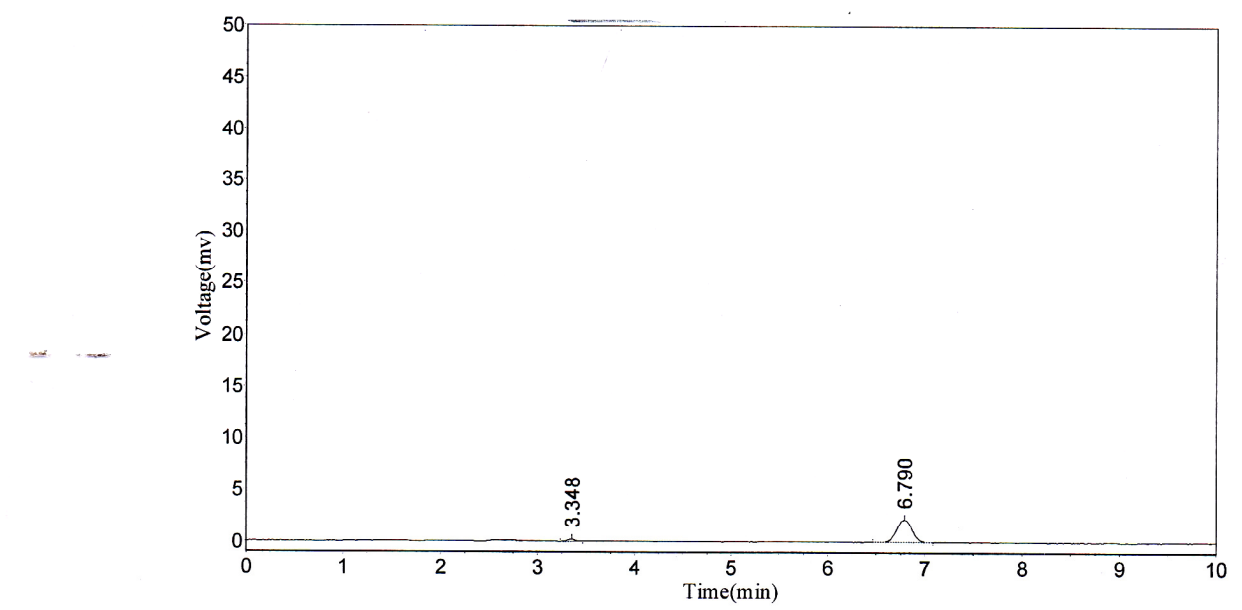

\begin{tabular}{|c|c|c|c|c|c|}
\hline \multicolumn{6}{|c|}{ Results } \\
\hline Peak No. & Peak ID & Ret Time & Height & Area & Conc. \\
\hline 1 & & 3.348 & 223.000 & 1141.900 & 4.4295 \\
\hline 2 & & 6.790 & 2187.840 & 24637.801 & 95.5705 \\
\hline Total & & & 2410.840 & 25779.701 & 100.0000 \\
\hline
\end{tabular}

\begin{tabular}{crrrrrrr} 
& \multicolumn{9}{c}{ System Evaluation } & & \\
Peak No. & Peak ID & Ret. Time & Half-Peak Width & Theoretical levels & Resolution & Tail Factor & Asymmetry \\
\hline 1 & 3.348 & 0.080 & 9704.813 & 0.000 & 1.059 & 1.091 \\
2 & 6.790 & 0.180 & 7883.231 & 13.237 & 1.043 & 1.099
\end{tabular}

\section{Precision}

Fig.-5: RT of the RMT (WS)

All precision studies were done with 150 ppm sample solution.

Six separate chromatograms took on the same day (Intraday precision) Table- 6 and an average of three chromatograms taken separately on three different days (Interday precision) Table-7 were studied to know the \% RSD of RT and PA. All the values met the criteria and confirm the closeness of the data to each other and the method was precise.

Table-7 were studied to know the \% RSD of RT and PA. All the values met the criteria and confirm the closeness of the data to each other and show that the method was precise.

\section{LOD}

The lowest concentration of the sample that can be detected under the developed conditions was calculated from the regression line as $1.32 \mathrm{ppm}$.

\section{LOQ}

The lowest concentration of the sample that can be detected with adequate precision and accuracy was 4.0 ppm. This was also calculated from the regression line. 
RASĀYAN J. Chem.

Vol. 11 | No. 1 |300 - 306 | January - March | 2018

\section{Robustness}

A small variation in the experimental conditions (Table-8) showed little or no effect on the average PA, RT, and \% RSD values and hence the method was Robust (Table-9).

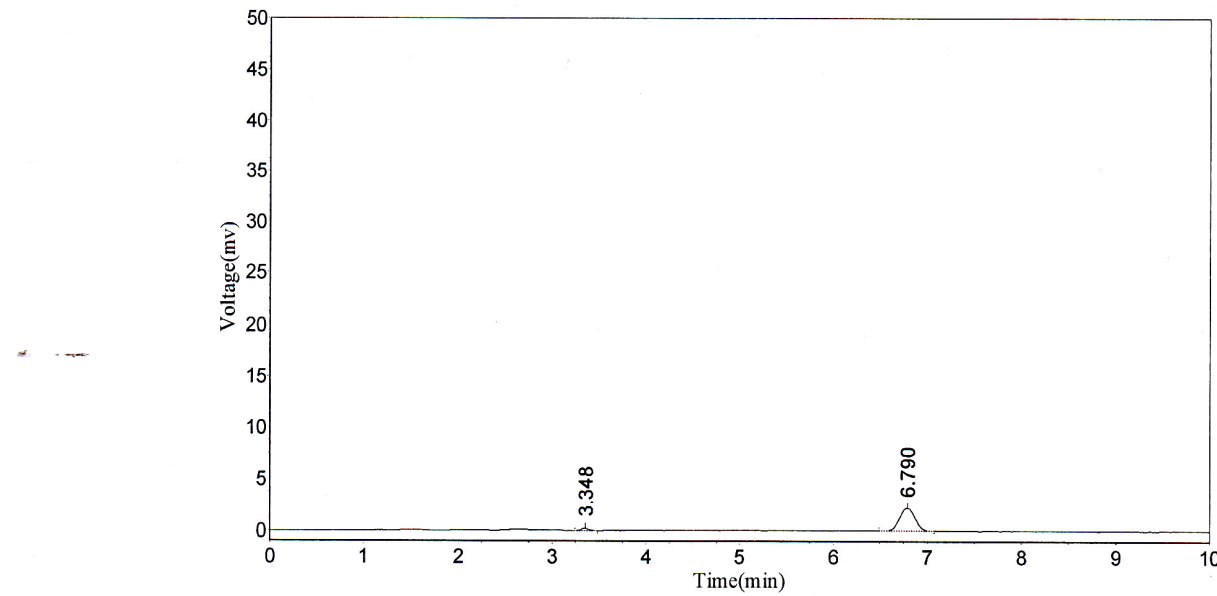

\begin{tabular}{|c|c|c|c|c|c|c|c|}
\hline \multicolumn{8}{|c|}{ Results } \\
\hline Peak No. & \multicolumn{2}{|c|}{ Peak ID } & Ret Time & \multicolumn{2}{|l|}{ Height } & Area & Conc. \\
\hline 1 & & & 3.348 & 204.379 & & 1049.300 & 4.0535 \\
\hline 2 & & & 6.790 & 2204.400 & & 24837.199 & 95.9465 \\
\hline Total & & 4 & & 2408.779 & & 25886.499 & 100.0000 \\
\hline \multicolumn{8}{|c|}{ System Evaluation } \\
\hline Peak No. & Peak ID & Ret. Time & Half-Peak Width & Theoretical levels & Resolution & Tail Factor & Asymmetry \\
\hline 1 & & 3.348 & 0.080 & 9704.813 & 0.000 & 1.174 & 1.275 \\
\hline 2 & & 6.790 & 0.178 & 8031.270 & 13.323 & 1.048 & 1.099 \\
\hline
\end{tabular}

Fig.-6: Sample Chromatogram

Table-6: Intraday Precision

\begin{tabular}{c|c|c|c}
\hline Trial & PA & RT & PH \\
\hline 1 & 74380.2 & 6.78 & 6533.1 \\
\hline 2 & 74605.7 & 6.78 & 6543.0 \\
\hline 3 & 72692.1 & 6.78 & 6453.7 \\
\hline 4 & 74263.9 & 6.78 & 6527.1 \\
\hline 5 & 74182.2 & 6.78 & 6519.9 \\
\hline 6 & 74611.9 & 6.79 & 6543.11 \\
\hline Mean & 74122.7 & 6.7816 & 6520.02 \\
\hline SD & 722.37 & 0.0040 & 33.722 \\
\hline \% RSD & 0.974 & 0.060 & 0.5172 \\
\hline
\end{tabular}

Table-7: Interday Precision

\begin{tabular}{c|c|c|c}
\hline Day & 1 & 2 & 3 \\
\hline Trial & PA & PA & PA \\
\hline 1 & 74128.3 & 74679.1 & 78485.7 \\
\hline 2 & 73211.8 & 75164.7 & 77627.5 \\
\hline 3 & 73323.7 & 75094.2 & 77530.7 \\
\hline Mean & 73554.6 & 74979.3 & 77881.33 \\
\hline SD & 500.01 & 262.42 & 525.62 \\
\hline \% RSD & 0.6797 & 0.3499 & 0.6749 \\
\hline
\end{tabular}


RASĀYAN J. Chem.

Vol. 11 | No. 1 | 300 - 306 | January - March | 2018

Table-8: Experimental Conditions

\begin{tabular}{c|c|c|c}
\hline Value & I & II & III \\
\hline Buffer $\mathrm{pH}$ & 6.6 & 6.7 & 6.8 \\
\hline $\begin{array}{c}\text { Column } \\
\text { Temp }\left({ }^{\circ} \mathrm{C}\right)\end{array}$ & 34 & 35 & 36 \\
\hline $\begin{array}{c}\text { Flow rate } \\
(\mathrm{ml} / \mathrm{min})\end{array}$ & 0.98 & 1.00 & 1.02 \\
\hline
\end{tabular}

Table-9: Robustness

\begin{tabular}{c|l|c|c|c|c|c|c|c|c}
\hline \multirow{2}{*}{ Value } & \multicolumn{3}{|c|}{$\mathrm{pH}$} & \multicolumn{3}{c|}{ Temp } & \multicolumn{3}{c}{ Flow rate. } \\
\cline { 2 - 10 } & 6.6 & 6.7 & 6.8 & 34 & 35 & 36 & 0.98 & 1.00 & 1.02 \\
\hline $\begin{array}{c}\text { Mean PA } \\
(\mathrm{n}=3)\end{array}$ & 76042.0 & 75090 & 76051 & 76001 & 75561 & 77490 & 79169 & 77251 & 76229 \\
\hline SD & 279.60 & 506.2 & 176.08 & 617.0 & 477.7 & 296.7 & 136.2 & 686.9 & 191.2 \\
\hline \% RSD & 0.367 & 0.6742 & 0.2315 & 0.811 & 0.6322 & 0.38 & 0.172 & 0.889 & 0.250 \\
\hline
\end{tabular}

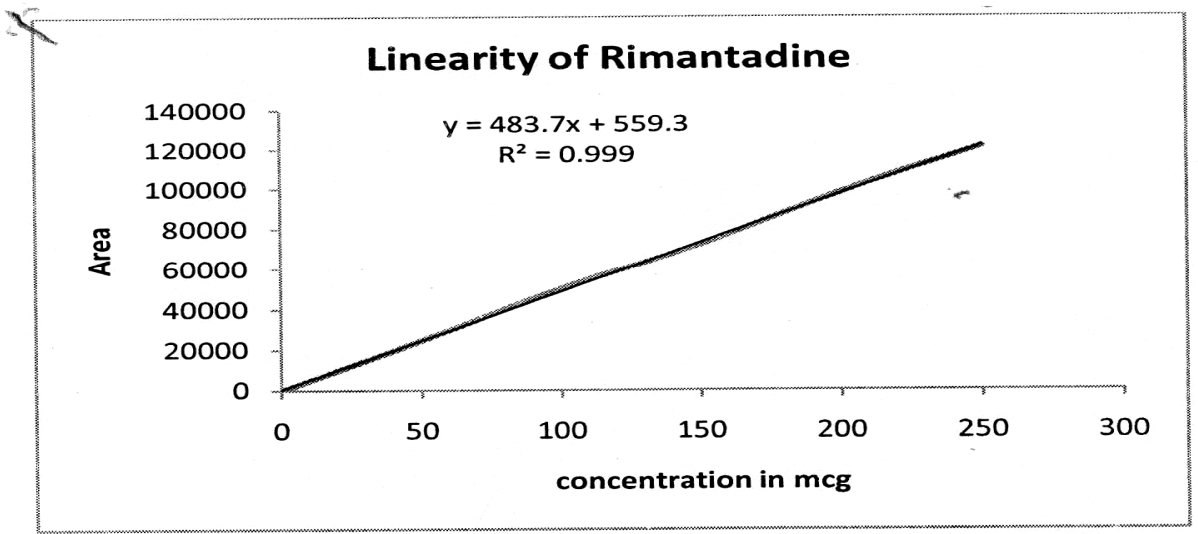

Fig.7: Linearity

\section{CONCLUSION}

The developed RP-HPLC method was selective, accurate, precise, and robust. All the validation measurables for the API and the sample were similar. The method can be used in quality control test.

\section{REFERENCES}

1. F. Feng, B. Lino, M. Goto, Talanta, 57(3), 481 (2002)

2. E.K. Fakuda, L.C. Rodriguez, N. Choma, N. Keigher, Biological Mass Spectrometry, 14(10), 549 (1987)

3. A.L. Revilla, J. Hamacek, P. Lubal, J. Havel, Chromatographia, 47(7-8), 433 (1998)

4. R.F. Suckow, Journal of Chromatography B, 764 (1-2), 313 (2001)

5. K.C. Zacharis, D.P. Tranavaros, A. Vlessidis, Journal of Separation Science, 36(11), 1720 (2013).

6. S.K. Vemuri, N. Ramyakrishna, M.J. Mohammed, B.N. Nalluri, British Journal of Pharmaceutical Research, 4(2), 278 (2014).

7. GQ. Wang, YF Qin, LM DU, JF Li, Spectrochemica Acta Part A, 98, 275, (2012).

8. A. Sobczak, I.Muszalska, P.Robowska, T. Inerowicz Drug development and Industrial Pharmacy, 39(5), 657 (2013).

9. H.Yan, X.Liu, F.Cui, H.Yun, Journal of Chromatography B, 938, 8(2013).

10. I. Muszalska, A. Sobczak, I. Kiaszewicz, Journal of Analytical Chemistry, 70(3), 320 (2015).

11. Y. Tsuruoka, T. Nakajima, M. Kanda, H. Hayoshi, Journal of Chromatography B, 142,1044 (2017)

12. https://www.pharmaguideline.com/2014/03/analytical-method-development-process -for new products.html.

13. http://www.gmp-compliance.org/guidemgr/files/Q2(R1).PDF

[RJC-2007/2017] 